\title{
Characterization of conservation units of the Central-West region of Brazil
}

\section{Caracterização das unidades de conservação da região Centro-Oeste brasileira}

Caracterización de las unidades de conservación de la región Centro-Oeste brasileña

Maycon Jorge Ulisses Saraia Farinha ${ }^{1}$ Luciana Virginia Mario Bernardo ${ }^{2}$ Vanderson Aparecido de Souza ${ }^{3}$ Luciana Ferreira da Silva ${ }^{4}$

${ }^{1}$ Mestre em Agronegócios, Licenciado e Bacharel em Geografia, ambos pela Universidade Federal da Grande Dourados (UFGD). E-mail: maycondds@hotmail.com

${ }^{2}$ Doutoranda em Desenvolvimento Regional e Agronegócios pela Unioeste, Mestre em Agronegócios e Bacharel em Ciências Contábeis, ambos pela UFGD. Universidade do Oeste do Paraná (Unioeste). E-mail: lucianamario@yahoo.com.br

${ }^{3}$ Mestrando em Agronegócios e bacharel em Ciências Contábeis pela UFGD. E-mail: vanderaparecido@hotmail.com

${ }^{4}$ Professora Doutora do Programa de Mestrado em Agronegócios da UFGD. Universidade Estadual de Mato Grosso do Sul (UEMS). E-mail: luciana@uems.br 


\begin{abstract}
The objective of this research is to characterize the existing conservation units in the Central-West region of Brazil, considering some aspects of the Presidential Decree No. 4.340/2002, which provides the necessary guidelines for the creation of conservation units. The choice of this region is due to its diversity of biomes. The deductive method was used for the elaboration of the research, starting with information about the country and sequentially about the chosen region. Even though there is a national registry of conservation units, there is a lack of information on these areas, because it is not filled in completely.
\end{abstract}

Keywords: environmental conservation; creation of conservation units; environment.

Resumo: O objetivo da pesquisa é caracterizar as unidades de conservação ambiental existentes na região Centro-Oeste do Brasil considerando alguns aspectos presentes no Decreto Presidencial n. 4.340/2002, que é o documento legal que explicita as características necessárias para a criação de unidades de conservação. Essa região foi neste estudo escolhida pela sua diversidade de biomas. Foi utilizado um método dedutivo para a confecção da imagem da área da pesquisa, para isso partindo de informações para o país e, sequencialmente, para a região escolhida. Observou-se que, mesmo havendo um cadastro nacional de unidades de conservação, existe carência de informações sobre essas áreas, pois tal cadastro, na maioria das vezes, é preenchido não por completo.

Palavras-chave: conservação ambiental; criação de unidades de conservação; meio ambiente.

Resumen: El objetivo de la investigación es caracterizar las unidades de conservación ambiental existentes en la región Centro-Oeste de Brasil considerando algunos aspectos presentes en el Decreto Presidencial n. 4.340 / 2002, que es el documento legal que explicita las características necesarias para la creación de unidades de conservación de conservación. Esta región fue en este estudio escogida por su diversidad de biomas. Se utilizó un método deductivo para la confección de la imagen del área de la investigación, para ello partiendo de informaciones para el país y, secuencialmente, para la región elegida. Se observó que, aun habiendo un registro nacional de unidades de conservación, existe carencia de informaciones sobre esas áreas, pues tal registro, la mayoría de las veces, se rellenan no por completo.

Palabras clave: conservación ambiental; creación de unidades de conservación; medio ambiente. 


\section{INTRODUCTION}

In Brazil, the Law no. 6.938, published in 1981, instituted the National Environmental Policy. Its intention was to create measures for the preservation of the environment, in order to integrate it with the social and economic aspects inherent to the society. In addition, the Law establishes the National Environmental System and the National Environmental Council, acting in a complementary way to regulate the guidelines of environmental licensing performed by states and municipalities. From this legislation, the country changes its perspective from preserving the landscape for its scenic beauty to the conservation of the ecosystem services offered by nature.

The importance of environmental preservation is reinforced, as it is inserted in the Article 225 of the Federal Constitution the security of the right of all Brazilians to have a balanced environment. Subsequently, Law number $9.985 / 2000$ is enacted to establish the National System of Nature Conservation Units (SNUC [BRASIL, 2006). In the SNUC are defined criteria and standards for the creation, execution and management of conservation units. The aim of SNUC is to guarantee a better quality of life for the local population and the region, from the creation of conservation units. Therefore, reducing the negative externalities of neighboring properties to the conservation unit.

The profiles of conservation units determine that these are of full protection (indirect use of natural resources) and sustainable use (sustainable use of natural resources). The full protection units are divided into five categories of preservation and the sustainable use units in seven. In these categories the objectives of preservation and the characteristics of each unit are defined. In the case of sustainable use units, it allows private preservation in one of its categories, all the others are public conservation areas. Therefore, considering the environmental services provided by these areas and the importance of environmental conservation, so that the Brazilian biodiversity can remain, the objective of the research is to characterize the conservation units in the Central-West region of Brazil. The choice of this region is due to its diversity of biomes. 


\section{MATERIAL AND METHODS}

In order to carry out the survey and characterize the existing conservation units in the Central-West region of Brazil, the deductive method was used to approach the problem, which allows starting from general questions to obtain answers for specific questions, using descriptive and bibliographic research. The number of these units in Brazil and by Brazilian regions were identified, specifying the number of areas, the percentage of the area of the protected biome and square kilometers preserved by categories. Afterwards, the description in the Decree No. 4.340/2002 was used, which refers to the indications that must be made at the time of the creation of conservation units, to characterize them in relation to: "management category, area of the unit and the institution responsible for its administration" (BRASIL, 2002, p. 1).

There was also a need to describe the conservation units regarding the biomes in which they are inserted, educational activities executed in the area, presence of residents of traditional, indigenous or quilombola population, availability of electricity, water supply, restroom, waste disposal and popular visitation. The data were collected on the website of the Ministry of Environment in the National Register of Conservation Units and organized by state of the Central-West region, in May of the respective year.

\section{RESULTS AND DISCUSSION}

\subsection{Characterization of conservation units in Brazil}

Table 1, shows the number of conservation units registered in Brazil. It also informs the number of these units by Brazilian region and the administrative level. The Southeast region has the largest number of protected areas created up to the time of the survey. It is also observed that only the Southeast region has a number of units created at the state level, higher than the number of protected areas created at the federal level. This characteristic may be related to the state public policies for creation incentive. From the total percentage, a decreasing ranking of the regions with the respective totals of the conservation units, being: Southeast, Northeast, North, Central-West and South. 
Table 1 - Conservation units by brazilian region

\begin{tabular}{lrlc}
\hline \multicolumn{1}{c}{ Region } & $\begin{array}{c}\text { Number of Conservation } \\
\text { Units }\end{array}$ & $\begin{array}{c}\text { Administrative } \\
\text { level }\end{array}$ & \% \\
\hline \multirow{3}{*}{ North } & 162 & Federal & 56 \\
& 118 & State & 41 \\
Total units in the region & 10 & Municipal & 3 \\
\hline \multirow{3}{*}{ Northeast } & $\mathbf{2 9 0}$ & \% Total & $\mathbf{1 4}$ \\
& 265 & Federal & 58 \\
Total units in the region & 181 & State & 40 \\
& 8 & Municipal & 2 \\
Central-West & $\mathbf{4 5 4}$ & \% Total & $\mathbf{2 2}$ \\
& 134 & Federal & 50 \\
Total units in the region & 118 & State & 44 \\
\hline \multirow{3}{*}{ Southeast } & 16 & Municipal & 6 \\
\hline Total units in the region & $\mathbf{2 6 8}$ & \% Total & $\mathbf{1 3}$ \\
\hline & 268 & Federal & 32 \\
South & 370 & State & 45 \\
& 190 & Municipal & 23 \\
\hline Total units in the region & $\mathbf{8 2 8}$ & \% Total & $\mathbf{3 9}$ \\
\hline Total Conservation Units & 140 & Federal & 56 \\
\hline
\end{tabular}

Source: Brasil (2017).

The conservation units created in the different Brazilian regions, as Laurance, Sayer and Cassman (2014) indicated allow the preservation of the ecosystem services of the different biomes that form Brazil. These territorial portions of conserved area provide the guarantee of the right established in the Federal Constitution for Brazilians in relation to the environment (BRASIL, 1988).

Table 2 establishes the relationship between the type, number of conservation units and biome. Regarding the type of conservation unit, there is a trend towards the creation of more units in sustainable use. It is justified, based on the notes made by Ayach, Bacani and Silva (2014), on the improvement of Brazilian legislation, in what refers to the conservation 
of environmental areas. Regarding the preservation of biomes, the Atlantic Forest has the largest number of conservation units, however, the area is proportional to $10 \%$ of the total area of the biome in Brazil. It should be pointed out that in the Brazilian Amazon biome, even not having the largest number of conservation units, it has the highest percentage of conserved area.

Table $\mathbf{2}$ - Number of conservation units by type and biome

\begin{tabular}{|c|c|c|c|c|c|c|c|c|c|c|c|c|}
\hline \multirow{3}{*}{ Kind } & \multicolumn{12}{|c|}{ Biomes } \\
\hline & \multicolumn{2}{|c|}{$\begin{array}{l}\text { Brazilian } \\
\text { Amazon }\end{array}$} & \multicolumn{2}{|c|}{ Caatinga } & \multicolumn{2}{|c|}{ Cerrado } & \multicolumn{2}{|c|}{$\begin{array}{l}\text { Atlantic } \\
\text { Forest }\end{array}$} & \multicolumn{2}{|c|}{ Pampa } & \multicolumn{2}{|c|}{ Pantana } \\
\hline & $\mathrm{N}^{1}$ & $\%^{2}$ & $\mathbf{N}^{1}$ & $\%^{2}$ & $N^{1}$ & $\%^{2}$ & $\mathrm{~N}^{1}$ & $\%^{2}$ & $\mathrm{~N}^{1}$ & $\%^{2}$ & $N^{1}$ & $\%^{2}$ \\
\hline $\mathrm{PI}^{3}$ & 82 & 10,2 & 39 & 1,2 & 120 & 3,1 & 376 & 2,5 & 13 & 0,4 & 7 & 2,9 \\
\hline$U^{4}{ }^{4}$ & 247 & 17,5 & 125 & 6,5 & 264 & 5,5 & 759 & 7,5 & 13 & 2,4 & 17 & 1,6 \\
\hline Total & 329 & 27,7 & 164 & 7,7 & 384 & 8,6 & 1.135 & 10 & 26 & 2,8 & 24 & 4,5 \\
\hline
\end{tabular}

1- Number of Conservation Units; 2- Percentage of the conserved area in relation to the total area of the biome; 3- Full Protection; 4- Sustainable Use Source: Brasil (2017).

From Table 2 it is possible to observe that the conservation units are located in the different biomes that exist in Brazil, but in a different way, both for the number of units created and in relation to the percentage of protection of the areas of the biomes. Sukhdev et al. (2010) considered that the conservation of areas assists in the maintenance of biodiversity and in the sharing of information regarding the intrinsic culture of space.

Table 3 provides information about conservation categories, biome and preserved area. It can be seen that there are no protected areas created for all categories in all biomes. The reason for this non-existence may be related to the considerations of Milaré (2011) on the creation of a conservation unit, following criteria established by the SNUC, among which the natural relevance aspect should be identified in the area and be related to the specific category of unit. In this context, two particular situations stand out, namely the Pantanal biome, which has four categories of conservation units, to which $36 \%$ of the preserved area is managed by private initiative and the Fauna Reserve category does not have any preserved area, among the biomes. 
For Brasil (2000) the Private Natural Heritage Reserve is constituted from the characteristic of the owner in conserving the biodiversity in their property or part of it. The creation of the conservation unit in this case comes from the owner's desire to preserve the environmental characteristics of the space. The Fauna Reserve, which is a gap in conservation units, is created by the government's decision to invest in technical-scientific studies that allow the sustainable management of wildlife resources. From the maintenance of native species of resident or migratory animals. In the latter case, there is a need for greater interest by public managers in the conservation of Brazilian fauna, so that there may be resources to invest in future research in the country.

Table 3 - Conservation area by category and biome

\begin{tabular}{|c|c|c|c|c|c|c|}
\hline \multirow{2}{*}{$\begin{array}{l}\text { Category } \\
\text { Integral Protection }\end{array}$} & \multicolumn{6}{|c|}{ Biome / Area in square kilometers } \\
\hline & $\begin{array}{l}\text { Brazilian } \\
\text { Amazon }\end{array}$ & Caatinga & Cerrado & $\begin{array}{l}\text { Atlantic } \\
\text { Forest }\end{array}$ & Pampa & Pantanal \\
\hline Ecological Station & 107.638 & 1.389 & 11.435 & 1.479 & 105 & 116 \\
\hline Natural Monument & 0 & 594 & 314 & 509 & 0 & 3 \\
\hline Parks & 268.724 & 7.601 & 48.692 & 23.260 & 392 & 4.285 \\
\hline Wildlife Refuge & 64 & 395 & 2.460 & 737 & 26 & 0 \\
\hline Biological Reserve & 52.856 & 70 & 81 & 2.453 & 105 & 0 \\
\hline \multicolumn{7}{|l|}{ Sustainable Use } \\
\hline Forest & 312.675 & 542 & 557 & 356 & 0 & 0 \\
\hline Extractive reserve & 137.749 & 19 & 883 & 712 & 0 & 0 \\
\hline $\begin{array}{l}\text { Sustainable } \\
\text { Development Reserve }\end{array}$ & 110.789 & 84 & 686 & 528 & 0 & 0 \\
\hline Wildlife Reserve & 0 & 0 & 0 & 0 & 0 & 0 \\
\hline $\begin{array}{l}\text { Environmental } \\
\text { Protection area }\end{array}$ & 173.643 & 52.294 & 108.504 & 80.960 & 4.214 & 0 \\
\hline $\begin{array}{l}\text { Area of Relevant } \\
\text { Ecological Interest }\end{array}$ & 446 & 198 & 87 & 271 & 14 & 0 \\
\hline $\begin{array}{l}\text { Private Natural } \\
\text { Heritage Reserves }\end{array}$ & 466 & 477 & 1.069 & 1.035 & 4 & 2.488 \\
\hline $\begin{array}{l}\text { Total conservation } \\
\text { area }\end{array}$ & 1.165 .051 & 63.673 & 174.769 & 112.300 & 4.861 & 6.891 \\
\hline
\end{tabular}

Source: Brasil (2017). 
The lack of conservation units in all biomes could be detrimental to biodiversity, once each category of conservation unit was established based on the valorization of national characteristics. Souza (2014) reinforces the importance of the existence of each of the conservation units, evidencing that the decision-making process to establish the guidelines of SNUC, demanded several discussions. However, even if they are based on international models, the categories of the protected areas were established based on the socio-environmental peculiarities of the country. Each of the categories are individual and irreplaceable.

\subsection{Characterization of conservation units in the Central-West region}

Table 4 indicates the number of conservation units by category, of the states that constitutes the Central-West Region. In relation to full protection, the State of Mato Grosso has the largest number of units (44\% of the total), of which are concentrated in the park category, approximately $69 \%$ of the conservation units. Regarding sustainable use, the number of conservation units in the State of Goiás is exponential (44\% of the total). The category with the greatest contribution to this number is the private natural heritage reserves, with a concentration of $75 \%$ of the units considered to be of sustainable use. It should be highlighted that, with the exception of the Federal District, the characterization of the number of protected areas indicates that the park and private reserve categories of natural heritage are those that stand out in relation to the number of units. The influence of public and private agents on the conservation of natural resources in the Central-West Region is perceptible. 
Tabela 4-Conservation units per state of the Central-West region of Brazil

\begin{tabular}{lcccc}
\hline Category & $\begin{array}{c}\text { Federal } \\
\text { District }\end{array}$ & Goiás & $\begin{array}{c}\text { Mato } \\
\text { Grosso }\end{array}$ & $\begin{array}{c}\text { Mato Grosso } \\
\text { do Sul }\end{array}$ \\
\hline Full Protection & 2 & 0 & 7 & 0 \\
$\begin{array}{l}\text { Ecological Station } \\
\text { Natural Monument }\end{array}$ & 1 & 0 & 1 & 3 \\
$\begin{array}{l}\text { Parks } \\
\text { Wildlife Refuge }\end{array}$ & 1 & 15 & 22 & 13 \\
Biological Reserve & 0 & 0 & 2 & 0 \\
\hline Total & 4 & 0 & 0 & 1 \\
\hline Sustainable Use & $\mathbf{8}$ & $\mathbf{1 5}$ & $\mathbf{3 2}$ & $\mathbf{1 7}$ \\
$\begin{array}{l}\text { Forest } \\
\text { Extractive reserve }\end{array}$ & 1 & 4 & 0 & 0 \\
Sustainable Development & 0 & 2 & 1 & 0 \\
Reserve & 0 & 0 & 0 & 0 \\
Wildlife Reserve & 0 & 0 & 0 & 0 \\
Environmental Protection area & 6 & 12 & 8 & 5 \\
$\begin{array}{l}\text { Area of Relevant Ecological } \\
\text { Interest }\end{array}$ & 13 & 1 & 0 & 0 \\
$\begin{array}{l}\text { Private Natural Heritage } \\
\text { Reserve }\end{array}$ & 5 & 58 & 20 & 37 \\
\hline Total & $\mathbf{2 5}$ & $\mathbf{7 7}$ & $\mathbf{2 9}$ & $\mathbf{4 2}$ \\
\hline
\end{tabular}

Source: Brasil (2017).

For Andrade and ladanza (2016) the creation of conservation units is complex due to different interests in the context, which requires the conviction of society about the need for this practice in order to have socioenvironmental sustainability. This process of conservation, for Andrade and Silva (2003) began in 1934 in the State of São Paulo, from Protective Forests, to which the scenic beauty of the landscape was valued. From this milestone, the legislations have been amended and the approach is expanded for the conservation of biodiversity.

Figure 1 shows the number of protected areas organized by hectare scale for the Central-West Region. It is observed that there are two extremes of numbers; the range from 1 to 100 hectares (61 units) and greater than 1000 hectares (122 units). These are considered to be the smallest and largest areas of units. Thus, it is indicated that the conservation units can 
have different sizes, and this is not a determining factor for their creation. It is noteworthy that there are conservation units in this region, with no information on the size of the area.

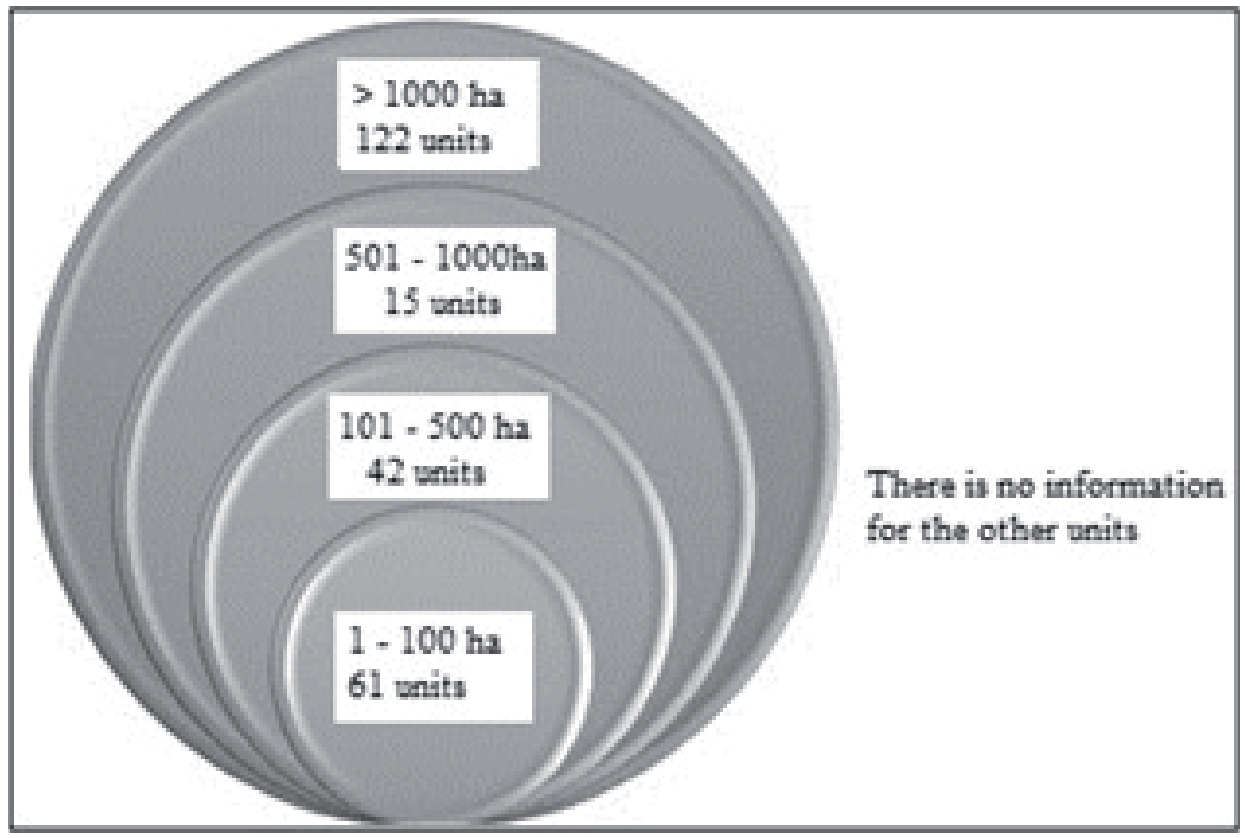

Figure 1 - Areas of the conservation units of the Central-West Region Source: Brasil (2017).

There is no minimum or maximum size to determine the creation of a conservation unit, which may be smaller than one hectare. However, the environmental characteristics in the area are indicative for the decisionmaking for the creation of the units. The technical inspection report, especially for private units, establishes if the area indicated for the creation of the conservation unit has attributes for the recognition of the same (BRASIL, 2012).

It is observed in Figure 2 that since the 1980s there has been a growth in the creation of conservation units in the states. In the case of the Federal District, there was a decline in the 1990s, but there was again a growth in 2000. 


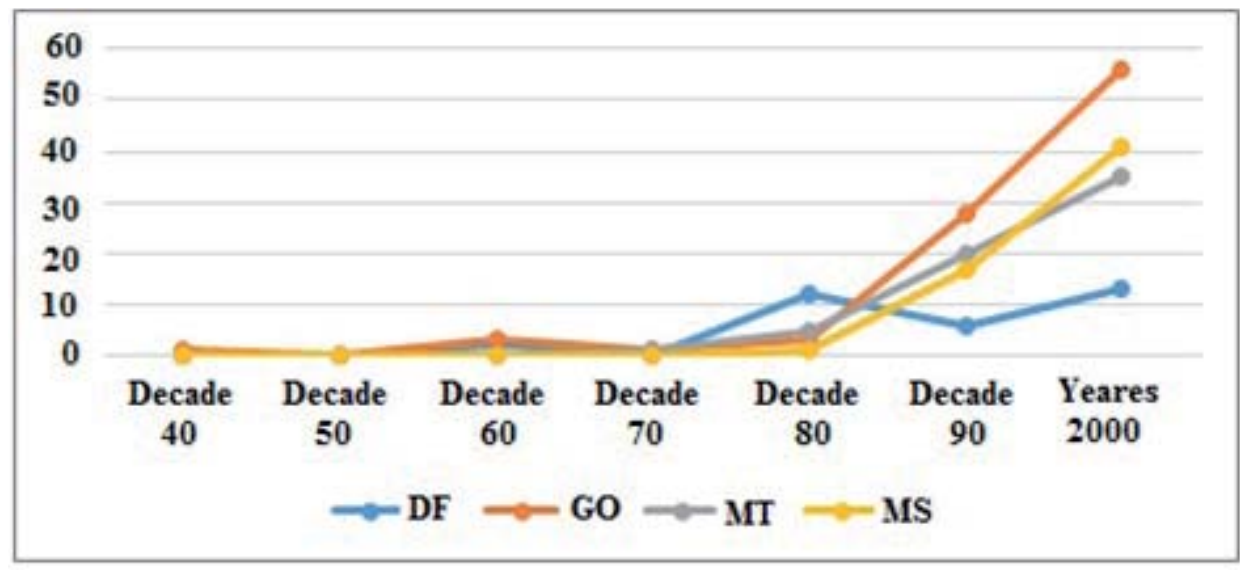

Figure 2 -Creation of conservation units in the brazilian Central-West region Source: Brasil (2017).

For Miller (1997) the human need in relation to natural resources is the justification for the creation and maintenance of protected areas. Conserving these spaces implies maintaining their cultural and historical characteristics. Vallejo (2002) understands these conservation units as territories. Studies developed in different areas of knowledge about the environment, help in the creation of these units by indicating the importance of conservation for the continuity of the existence of different natural resources.

In relation to the biomes, in which the conservation units are in, there is a range of all biomes present in the Central-West region of the country, to a greater or lesser extent: all the conservation units of the Federal District conserve the Cerrado biome; Goiás $99 \%$ of the conservation units conserve the Cerrado biome and 1\% Caatinga; Mato Grosso 46\% the Cerrado biome, $42 \%$ the Brazilian Amazon biome and $12 \%$ the Pantanal biome and in Mato Grosso do Sul 56\% of the units conserve the Cerrado biome, 24\% the Pantanal biome and $20 \%$ the Atlantic forest biome. 


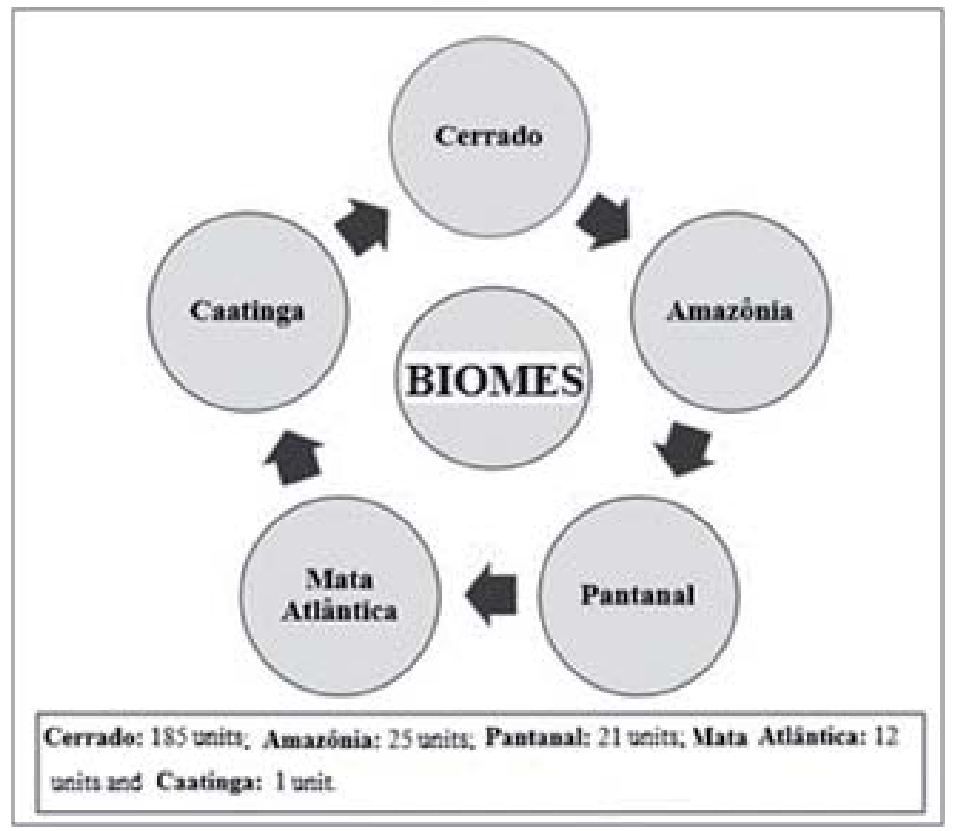

Figure $\mathbf{3}$ - Biomes present in the conservation units of the Central-West region

Source: Brasil (2017).

The conservation units created in the Central-West Region of Brazil contribute to the responsibility that the country has, according to Rylands and Brandon (2005), in maintaining the biodiversity identified in its territory. Considering the scope of the number of biomes conserved with these units and consequently their biodiversity in each case. Mainly, as regards the maintenance of environmental areas in the Cerrado biome, which is in danger.

The management plan (Figure 4) is important for the management process of protected areas. The document is created from the objectives of the unit. It is described, in the management plan, from the characteristics of the conservation units to the way the activities in the units are developed. Most of the conservation units state that they do not have a management plan, but for Brasil (2000) all units must have their own plan, within five years after the unit is created. Considering the creation year of the conservation units in the national system, most of these units should have this document elaborated. 


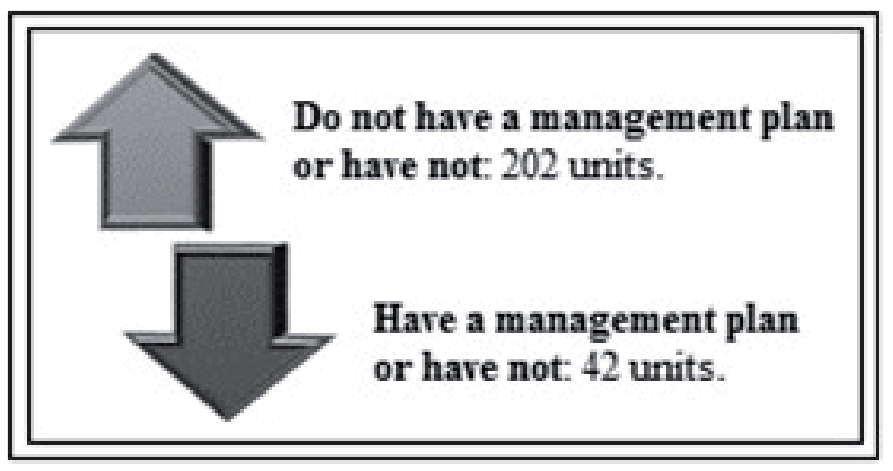

Figure 4 - Information on the management plan Source: Prepared from the Brasil (2017).

Among the benefits presented by the conservation units is the possibility of access to visitation and in some cases the development of other activities in the areas. This characteristic can help in the development of environmental education, which contributes to the citizen training of individuals to broaden environmental conservation practices. It is observed that the units located in the Central-West Region, have little information about the accessibility of visitation (196 without information). In addition, the number of conservation units without access to visitation (30 units) is greater than the result of the addition (18 units) between open units or with special permit for visitation (Figure 5). 


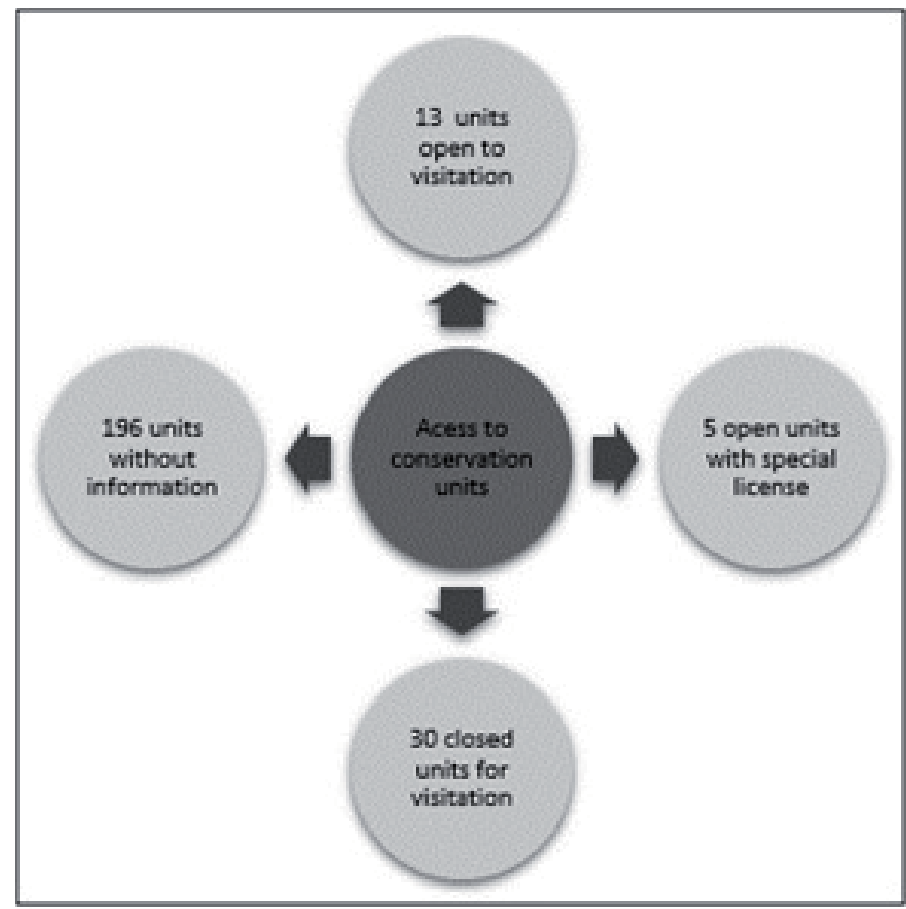

Figure 5 - Visiting the conservation units Source: Brasil (2017).

The visitation of the conservation units can help with the achievement of the objectives of each unit category, described by Brasil (2000). It is believed that individuals who have access to these areas can receive instructions that help in understanding the importance of creating and maintaining these units to reduce the environmental impacts that different human activities produce in relation to the environment. For Barnosky et al. (2011) and Pimm et al. (2014) the relationship between individuals and the environment can result in increased biodiversity loss if there is no care to reduce the impacts that can be caused.

Regarding the existing practices of Environmental Education in these spaces, the available information indicates that of the total conservation areas, 24 units developed activities related to this education format. However, most of these spaces (195 units) do not provide information about these practices and 24 units do not develop them. 


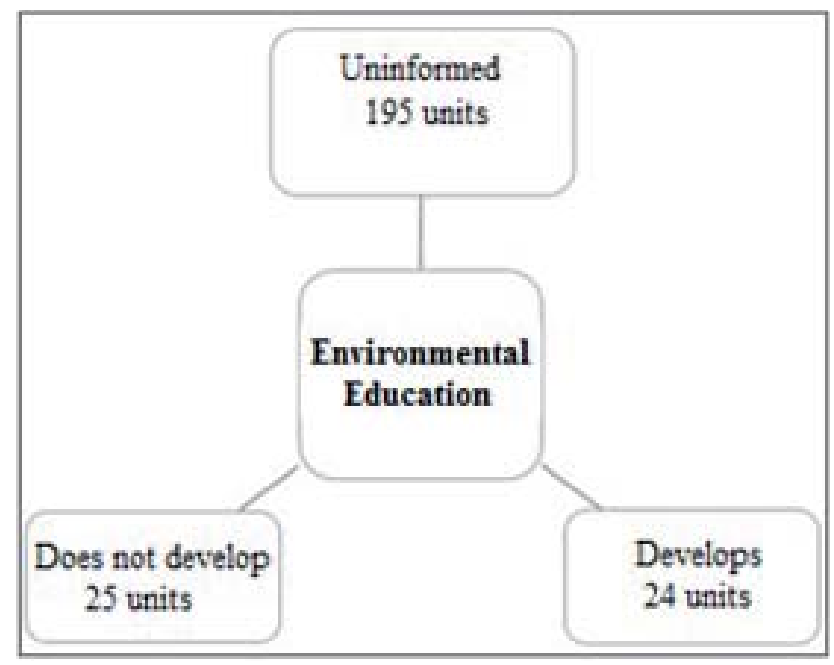

Figure 6 -Environmental education in conservation units in the Central-West region Source: Brasil (2017).

Environmental Education Practices may contribute to Brasil (1988) intention in relation to the creation of conservation units so that future generations can have access to the environmental characteristics in Brazil, that is, to all the biodiversity existing in the country, therefore, conveys information to educate people about the need to preserve the environment. Machado (2012) points out that requirements are made for the opening of the visitation in conservation units, based on measures of protection and safety for visitors who contemplate the maintenance and recommendations necessary to this practice, without causing environmental impacts.

In relation to the infrastructure in these units considering electric energy (Figure 7), a high number of units did not provide information. Those who disclose information, network energy is predominant (39 units), the renewable energy system ( 5 units). Considering that the purpose of these units is to preserve the nature or other tangent regarding this situation, it is advisable to invest in renewable energy systems in these spaces. 


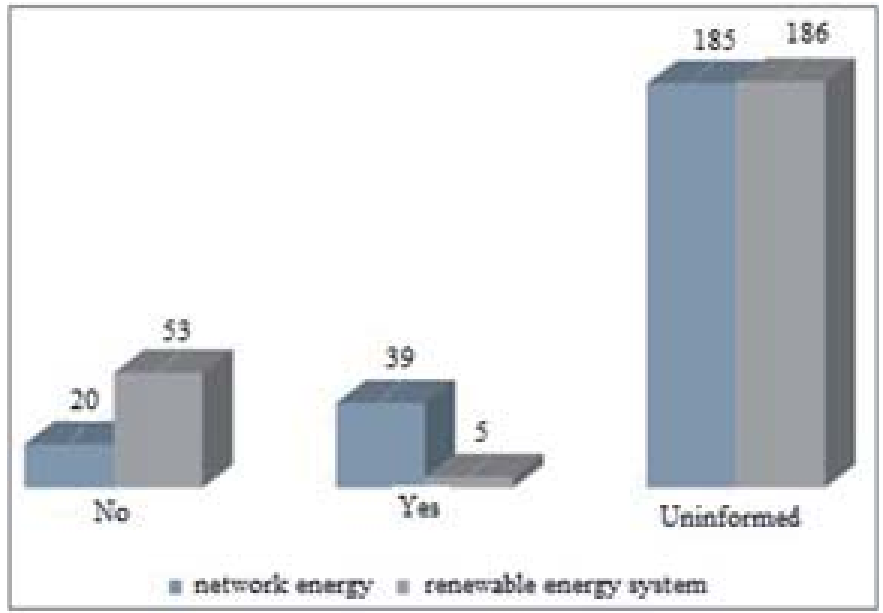

Figure 7 - Information on electric power

Source: Brasil (2017).

In Figure 8, regarding basic sanitation, there is a lack of information about the units of conservation. There is water supply in 23 units and restrooms in 30 units. The waste disposal is in cesspools in 34 units.

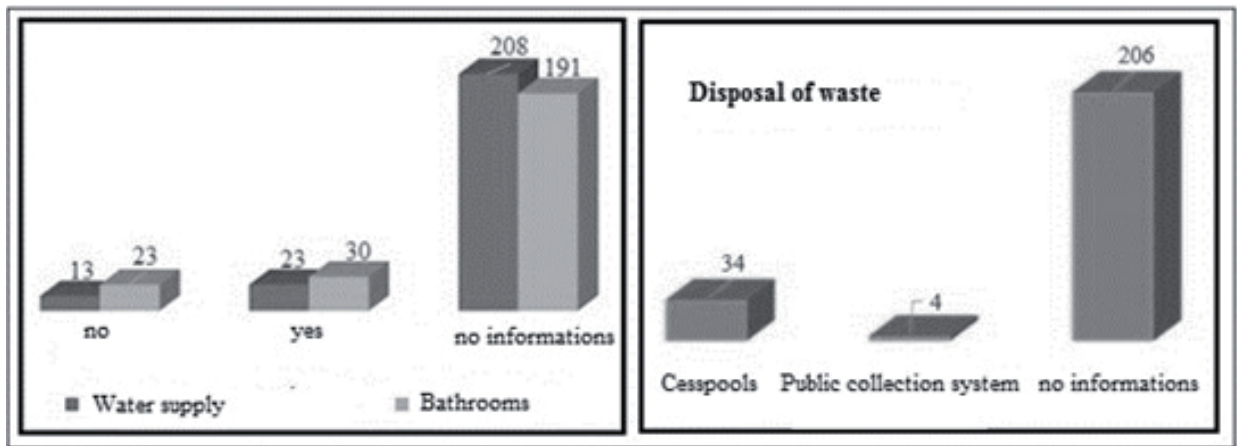

Figure $\mathbf{8}$ - Basic sanitation information

Source: Prepared from the Brasil (2017).

The characterization of the structural information of conservation units is important to indicate the need for improvements if there is investment in environmental education within these areas. In addition, seven units were identified with residents of traditional, indigenous or quilombola population. 
Other 111 units do not disclose this information. Thus, in the units where this population lives, infrastructure can be a measure of disease prevention for them. Another important aspect for conservation units is the agencies responsible for enabling their creations and supervising the units. In Chart 1 it is possible to identify the federal, state and municipal performance in these organs, in different amounts per state.

\begin{tabular}{|c|c|c|c|}
\hline Federal District & Goiás & Mato Grosso & Mato Grosso do Sul \\
\hline $\begin{array}{l}\text { Instituto Chico } \\
\text { Mendes de Con- } \\
\text { servação da Bio- } \\
\text { diversidade; } \\
\text { Instituto do } \\
\text { Meio Ambiente } \\
\text { e dos Recursos } \\
\text { Hídricos do Dis- } \\
\text { trito Federal. }\end{array}$ & $\begin{array}{l}\text { Instituto Chico } \\
\text { Mendes de } \\
\text { Conservação da } \\
\text { Biodiversidade; } \\
\text { Secretaria Es- } \\
\text { tadual do Meio } \\
\text { Ambiente e dos } \\
\text { Recursos Hídri- } \\
\text { cos de Goiás; } \\
\text { Secretaria Mu- } \\
\text { nicipal de Meio } \\
\text { Ambiente de } \\
\text { Catalão; } \\
\text { Secretaria Mu- } \\
\text { nicipal do Meio } \\
\text { Ambiente de } \\
\text { Mambaí; } \\
\text { Prefeitura Mu- } \\
\text { nicipal de Pira- } \\
\text { canjuba. }\end{array}$ & $\begin{array}{l}\text { Instituto Chico } \\
\text { Mendes de Con- } \\
\text { servação da Bio- } \\
\text { diversidade; } \\
\text { Secretaria de } \\
\text { Estado do Meio } \\
\text { Ambiente de } \\
\text { Mato Grosso; } \\
\text { Secretaria Mu- } \\
\text { nicipal de Meio } \\
\text { Ambiente e } \\
\text { Assuntos Fundi- } \\
\text { ários; } \\
\text { Secretaria de } \\
\text { Agricultura, Pe- } \\
\text { cuária, Fomento } \\
\text { e Meio Ambien- } \\
\text { te; } \\
\text { Prefeitura de } \\
\text { Sinop. }\end{array}$ & $\begin{array}{l}\text { Instituto Chico Mendes de } \\
\text { Conservação da Biodiversi- } \\
\text { dade; } \\
\text { Instituto de Meio Ambiente } \\
\text { do Mato Grosso do Sul; } \\
\text { Secretaria Municipal de } \\
\text { Meio Ambiente; } \\
\text { Secretaria Municipal de De- } \\
\text { senvolvimento, Agricultura, } \\
\text { Pecuária, Turismo e Meio } \\
\text { Ambiente de Alcinópolis; } \\
\text { Secretaria de Desenvolvi- } \\
\text { mento Econômico e Meio } \\
\text { Ambiente de Chapadão do } \\
\text { Sul; } \\
\text { Secretaria Executiva de Meio } \\
\text { Ambiente de Corumbá; } \\
\text { Instituto de Meio Ambiente } \\
\text { de Dourados; } \\
\text { Prefeitura Municipal de } \\
\text { Naviraí }\end{array}$ \\
\hline
\end{tabular}

Frame 1 - Agencies responsible for conservation units registered by state in the Central-West region

Source: Brasil (2017).

For Figueiredo et al. (2017) the supervision carried out by these governmental agencies, promote the fulfillment of the objectives of creation of the units. In this way, they are important so that the units of conservation maintain the profile of environmental conservation defined in its creation. Therefore, assisting the managers of the areas to maintain the biodiversity 
and the practices allowed and established in the management plan created specifically from the characteristics of the unit.

\section{FINAL CONSIDERATIONS}

The objective of the article was to characterize the existing conservation units in the Center-West region of Brazil. The availability of information was verified on the website of the Ministry of Environment, through the National Register of Conservation Units. The information contained on this website covers different elements that are beyond Decree 4.340/2002, which refers to the indications that must be made at the time of the conservation units' creation.

It was noticed that not all conservation units created in the CentralWest Region of Brazil are registered in the system. In the specific information, 245 registered units were identified; however in the national information 268 units are registered in the Central-West Region of Brazil. In addition, during the data collection, it was noticed that many conservation units do not register information besides those considered basic information, such as name, year of creation, biome, size of area, among others. This makes the registration incomplete.

The proposal for the creation of the national system is an important measure to broaden the discussions about the maintenance of biodiversity; it also allows the creation of knowledge on the different contexts in which conservation units are created. Meantime, the peculiarity of the system, with incomplete information, indicates the need for improvements in it and the transparency of information regarding the conservation of Brazilian biodiversity.

Conservation units are considered areas which enable future generations to access the different environmental characteristics in Brazil. They contribute to the reduction of environmental impacts caused by man, but environmental education practices need to be directed towards sharing knowledge about the need to conserve the environment. The qualification of the people that develop the process of management of the units and the supervision of the governmental institutions can foment this practice and consequently the increase of the creation of these units. 


\section{REFERENCES}

ANDRADE, J. T.; SILVA, J. A. Categorias de florestas estabelecidas nos Códigos Florestais de 1934 e 1965. Floresta e Ambiente, v. 10, n. 2, p. 78-86, 2003.

ANDRADE, M. P.; IADANZA, E. E. S. Unidades de Conservação no Brasil: algumas considerações e desafios. Revista de Extensão e Estudos Rurais, v. 5, n. 1, p. 8196, 2016.

AYACH, L. R.; BACANI, V. M.; SILVA, J. F. Unidades de conservação no Pantanal do município de Aquidauana-MS: uma análise da evolução do uso da terra e cobertura vegetal e suas implicações. Caderno de Geografia, v. 24, n. 42, p. 138-54, 2014.

BARNOSKY, A. D.; MATZKE, N.; TOMIYA, S.; WOGAN, G. O. U.; SWARTZ, B.; QUENTAL, T. B.; MARSHALL, C.; MCGUIRE, J. L.; LINDSEY, E. L.; MAGUIRE, K. C.; MERSEY, B.; FERRER, E. A. Has the Earth/'s sixth mass extinction already arrived? Nature, n. 471, p. 51-7, 2011.

BRASIL. Consulta - Relatórios de UC. 2017. Disponível em: <http://www.mma.gov. br/areas-protegidas/cadastro-nacional-de-ucs/consulta-gerar-relatorio-de-uc>. Acesso em: 20 abr. 2017.

. Ministério do Meio Ambiente. Instituto Chico Mendes de Conservação da Biodiversidade. Perguntas e respostas sobre reserva privada do patrimônio natural. Brasília, 2012.

. Ministério do Meio Ambiente. SNUC: Sistema Nacional de Unidades de Conservação da Natureza. Brasília, 2006.

Constituição da República Federativa do Brasil. Brasília, DF: Senado Federal: Centro Gráfico, 1988. 292p.

. Decreto n. 4.340, de 22 de agosto de 2002. Regulamenta artigos da Lei no 9.985, de 18 de julho de 2000, que dispõe sobre o Sistema Nacional de Unidades de Conservação da Natureza - SNUC, e dá outras providências. Disponível em: <http://ideflorbio.pa.gov.br/wp-content/uploads/2015/08/Decreto_4340.pdf>. Acesso em: abr. 2017

. Lei n. 9.985, de 18 de julho de 2000. Regulamenta o art. 225, § 10, incisos I, II, III e VII da Constituição Federal, institui o Sistema Nacional de Unidades de Conservação da Natureza e dá outras providências. 2000. Disponível em: <http:// www.mma.gov.br/port/conama/legiabre.cfm?codlegi=322>. Acesso em: abr. 2017 FIGUEIREDO, H. P.; CONTANTINO, M.; BARROS, J. H. S.; COSTA, R. B. Políticas públicas e fragilidades na gestão de Unidades de Conservação Urbanas no Brasil. Multitemas, Campo Grande, MS, v. 22, n. 51, p. 217-34, jan./jun. 2017.

LAURANCE, W.; SAYER, J.; CASSMAN, K. G. Agricultural expansion and its impacts on tropical nature. Trends Ecology Evolution, v. 29, n. 2, p. 107-16, fev. 2014. 
MACHADO, P. A. L. Direito Ambiental Brasileiro. 20. ed. São Paulo: Malheiros, 2012.

MILARÉ, E. Direito do Ambiente: a gestão ambiental em foco. 7. ed. rev., atual. e reformulada. São Paulo: Revista dos Tribunais, 2011.

MILLER, K. R. Evolução do conceito de áreas de proteção - oportunidades para o século XXI. In: CONGRESSO BRASILEIRO DE UNIDADES DE CONSERVAÇÃO, 1., p. 3-21, 1997. Anais... Curitiba: IAP; UNILIVRE; Rede Nacional Pró Unidades de Conservação. 1997.

PIMM, S. L.; JENKINS, C. N.; ABELL, R.; BROOKS, T. M.; GITTLEMAN, J. L.; JOPPA, L. N.; RAVEN, P. H.; ROBERTS, C. M.; SEXTON, J. O. The biodiversity of species and their rates of extinction, distribution, and protection. Science, n. 344, p. 987-98, 2014.

RYLANDS, A. B.; BRANDON, K. Unidades de conservação brasileiras. Megadiversidade, v. 1, n. 1, p. 24-35, 2005.

SOUZA, T. B. M. A sistematização das unidades de conservação da natureza em categorias de manejo. Conhecimento Interativo, v. 8, n. 1, p. 161-85, 2014.

SUKHDEV, P.; WITTMER, H.; SCHRÖTER-SCHLAACK, C.; NESSHÖVER, C.; BISHOP, J.; BRINK, P.; GUNDIMEDA, H.; KUMAR, P.; SIMMONS, B. Mainstreaming the economics of nature: a synthesis of the approach, conclusions and recommendations of TEEB. The Economics of Ecosystems \& Biodiversity, n. 51, 2010.

VALLEJO, L. Unidade de Conservação: uma discussão teórica à luz dos conceitos de território e políticas públicas. GEOgraphia, Niterói, RJ, v. 4, n. 8, p. 57-78, 2002. 